\title{
Remaking the Moral Person in China: Implications for Health
}

\section{Citation}

Kleinman, Arthur. 2010. Remaking the Moral Person in China: Implications for Health. The Lancet 375(9720): 1074-1075.

\section{Published Version}

doi:10.1016/S0140-6736(10)60466-7

\section{Permanent link}

http://nrs.harvard.edu/urn-3:HUL.InstRepos:5142655

\section{Terms of Use}

This article was downloaded from Harvard University's DASH repository, and is made available under the terms and conditions applicable to Open Access Policy Articles, as set forth at http:// nrs.harvard.edu/urn-3:HUL.InstRepos:dash.current.terms-of-use\#OAP

\section{Share Your Story}

The Harvard community has made this article openly available.

Please share how this access benefits you. Submit a story.

\section{Accessibility}


Remaking the Moral Person in the New China: Implications for Health and Medicine Arthur Kleinman Harvard University Introduction

By 2020 China's economy is predicted to become the world's largest. That year almost half a billion Chinese will qualify as middle class—a spectacular and unprecedented instance of poverty reduction and the building of widespread prosperity over just four decades. China now holds two trillion dollars in foreign revenues. Chinese will have soon become the dominant language on the internet. Now the largest manufacturer of global goods, China will, by 2020, become the largest domestic market too. And its political, military, and cultural power is growing apace.

Yet the Chinese of today and tomorrow will look hardly at all like the Chinese of the past. Demographically, an ancient agrarian society has entered an increasingly urban modernity. Now, for the very first time more Chinese are over 60 years of age than are under 5 years. And the one-child-per-family policy places a greater and 
greater burden of security and care of the elderly on an ever-narrowing number of workers. That same policy has had the unanticipated consequences of fostering a society-wide sexual revolution. Meanwhile, women, who now, owing to sex selection, are in a minority, are striving for and achieving a higher status with growing rates of wife-originated divorce.

China, still officially an atheistic state controlled by the Communist Party, is also experiencing, something of a revolution in religion and morality. There are millions of families reviving Chinese folk religion—a popular blend of Buddhism, Confucianism, and Taoism centered on ancestor reverence-while Buddhist temples and worship have returned to popularity. There are between 70 and 100 million Christians, and more than 100 million Muslims. At the same time, the newspapers are filled with accounts of official corruption, the marketing of unsafe medication and tainted food, and a crescendo of distrust of local cadres. Mistrust of physicians is also at an all-time high, and malpractice and malfeasance litigation against doctors, hospitals, and also teachers is rising. Empty Communist political rhetoric, continuing resentment over the cruel repression of the radical-Maoist past, and 
disgust with the reemergence of prostitution, crime, and violence have fueled an epidemic of cynicism; popularized by such sayings as "What is Communism? The longest and most painful road to Capitalism." Raw nationalism, intensified Han chauvinism, worsening relations with ethnic minorities, and rising frustration with Europe and America indicate that moral change is occurring on a number of levels. One change of potentially far reaching significance for health and medicine has to do with the remaking of the moral life of Chinese individuals. To begin with, there is increasing evidence from social science research that under the pressure of globalization, individualization is rapidly occuring with deepening autonomy, materialistic consumer desire, and blatantly overt self-interest with a concomitant emphasis on conjugal over parental relations, the development of an urban youth culture, and rising rates of certain forms of behavioral problems: e.g., depression, eating disorders, attention deficit hyperactivity, substance abuse, sexually transmitted diseases, and suicide.

Yet, the making of a modern subjectivity is not all negative. There is also substantial evidence of greater altruism, critical self-reflection on the roots and 
results of corruption and other social problems, and protest and advocacy

concerning environmental issues, food safety, and public health. For example, against the expectations of the Party, Shenzhen and other Chinese cities have shifted from a blood supply based on coercion and paying professional blood donors (associated with a catastrophic HIV/AIDS epidemic caused by illegal and government blood purchasing practices) to one based on voluntary citizen donation. Another instance is the huge number of volunteers who responded to the Sichuan earthquake. There is also a great increase in NGOs, few of which are officially registered and regulated. The rise of a large middle class who use the internet, travel abroad, and demand world quality services and goods is matched by the state's ideological transformation from the central tenant of the era of radical Maoism that the Chinese individual owes his/her life to the party-state to the seemingly ordinary, but for the Chinese truly extraordinary proposition that the state owes the individual a chance at a good life.

Viewers of the Beijing Olympics saw thousands of ordinary Chinese just enjoying themselves-a situation largely without precedent in modern Chinese 
history. The quest for personal happiness, at least among the middle class, who are expected to number $500,000,000$ in 2020 , is now normative and normal, replacing the quest to endure the bitterness of hard times that had been China's folk wisdom for centuries. Grievances over past humiliation by the West are being replaced by a gathering sense that it may be the moment, as one China watcher titles his recent book, When China Rules the World (2009). And there is also expression of a growing interest in psychotherapy and hunger for spirituality.

\section{$\underline{\text { Some Implications }}$}

Epidemics of sexually transmitted disease, substance abuse, obesity-related diabetes and heart disease, cigarette smoking and mental health problems are directly related to these new subjectivities and behaviors, and hold clear implications for public health. They have rightly attracted the concern of many foreign commentators and the Chinese themselves. In what follows, I want to trace the potential implications of individual change for another side of Chinese society: ethics, the development of professionalism and the quest for meaning in everyday life. 
While China possesses a marvelously rich indigenous tradition of Confusion ethics, medical ethics in contemporary Chinese hospitals, medical schools and biotechnology research institutes is still largely an import of Euro-American, and indeed principally NIH-based, procedures and protocols. As such, it seems to lack the intense concern found in Europe and America, and is often grudgingly treated as a necessary after-thought for which cosmetic and highly technical responses are sufficient.

This delayed development of a concern for values in medicine was substantially encouraged in China (and in Japan) by the failure to provide justice for the wartime medical atrocities of the Japanese Imperial Army's extensive biowarfare program. Instead, the occupying American regime prevented a trial of the doctors and scientists responsible, inter alia, for dropping anthrax bombs on Chinese cities and vivisecting each year from 1937-1945 more than a thousand Chinese research subjects of grotesquely inhuman experiments. In return for helping America co-opt the Japanese bio-warfare expertise, there was no equivalent to the Nuremberg Trials for Nazi doctors. And hence there is no East Asian 
equivalent of the Nuremberg Code for medical ethics. Lacking that powerful stimulus, medical ethics in China has been anemic. Yet, there is in this decade, deepening interest in professional ethics promoted by both concern for controlling corruption and dangerous and unnecessary medical practices and by a health equivalent to the consumer consciousness movement that is affecting the rest of Chinese society. Students and professionals are drawing on the broadening, societywide critical reflection on patient-doctor value conflicts and the inadequacy of health and welfare security to build a more robust ethics.

At the same time, the medical profession, like the legal, architectural, engineering and other professions, is self-consciously professionalizing with greater attention to best practices, training standards, and public responsibilities. The workunit (e.g. hospital), which was both the center of the micro-politics of Chinese society and of value concerns in the era of collectivism, is giving way to the individual professional as a self-authorizing moral agent responsible for quality of practice. Of course, there are, in an authoritarian society ruled by an illiberal partystate, real limits to what can be achieved by individuals and their professional 
associations; yet something transformative is afoot and the state's new found concern for good governance is enabling its development, within the acceptable political boundaries of course.

In this respect, China's current "psycho-boom" is instructive. The huge awakening interest in psychology books, biographical documentary, films, counseling, psychological idioms of distress, psychometric methods, and training in psychotherapy has caught even China watchers off guard. While it is easy to dismiss the superficiality of this popular interest and the absence of standards to authorize clinical competence in this area, it would be a major mistake to fail to recognize that this big city, middle-class movement represents a deeper and broader set of quests for meaning in everyday life among ordinary Chinese that holds the potential to transform Chinese culture and society.

Individuals in today's urban China are connected via the internet, the media, and in the hundreds of ways that globalization has stitched all of us together into a global culture. Of the many ramifications of this true cultural revolution, perhaps the most telling for Chinese is the emphasis it is placing on a self divided between 
increasingly anachronistic internalized political and cultural restrictions and inner liberation of meaning, emotions, and aspiration. The tension between one eye open to the world as it is and one eye closed to protect and promote not just self interest but yearning for a better world is an old idea in Chinese society, one that is enabled by hypocrisy and the greater importance of personal connections over rules. yet today it gains renewed relevance from an outside world that is more conducive to pro-social moral change and an inner subjectivity that is either less willing to collude in things as they are or freer to imagine and practice different ways of inhabiting that new world.

The upshot is that the Chinese and their practical values are a force for change in many domains, from health and medicine to education and the environment. And society and the new subjectivity are here to stay. Will they change the political reality as they have so visibly altered economic and technological affairs? No one knows. But the profession of medicine will not be the same; nor will the ethics of the doctor-patient relationship and health research. The demand for quality caregiving may well change forever the health care system. 
